\title{
Téoros
}

Revue de recherche en tourisme

\section{A Vision for Ecotourism on the Lower North Shore of Quebec}

\section{John S. Hull}

Volume 21, numéro 3, automne 2002

Écotourisme

URI : https://id.erudit.org/iderudit/1072503ar

DOI : https://doi.org/10.7202/1072503ar

Aller au sommaire du numéro

\section{Éditeur(s)}

Université du Québec à Montréal

\section{ISSN}

0712-8657 (imprimé)

1923-2705 (numérique)

Découvrir la revue

\section{Citer cet article}

Hull, J. S. (2002). A Vision for Ecotourism on the Lower North Shore of Quebec. Téoros, 21(3), 50-56. https://doi.org/10.7202/1072503ar d'utilisation que vous pouvez consulter en ligne.

https://apropos.erudit.org/fr/usagers/politique-dutilisation/ 


\section{A Vision for Ecotourism on the Lower North Shore of Quebec}

\section{John S. Hull}

M any policymakers argue that the sustainability of ecotourism is dependent upon a principled and proactive supply-side approach to development (Blamey, 2001; Ross and Wall, 1999; Buckley, 1994). In general, discussion of sustainable tourism development over the last two decades has focused on initiatives to develop strategies, guidelines, and indicators that revolve around principles such as:

- holistic planning and strategy-making;

- preservation of essential ecological processes;

- protection of both human heritage and biodiversity;

- development to ensure that productivity can be sustained for future generations (Bramwell and Lane, 1993).

The major challenge for many destinations has been implementing principles to provide a useful way forward-putting theory into practice (Boyd, 2000).

The purpose of this paper is to analyse the efforts of the Centre local de développement (CLD) on the Lower North Shore of Quebec to develop a small-scale ecotourism industry in the region. The first section of the paper defines the LNS region to provide a context for analysis. The second section analyses the five-year plan for ecotourism development completed in 2002 applying Blamey's (2001) three dimensions of ecotourism-nature-based, environmentally and culturally educative, and sustainably managed-to evaluate how well those concepts have been integrated into the plan. The last section provides concluding remarks and argues that the sustainability of ecotourism in the region will depend on the financial and technical support of public and private agencies in implementing the plan.

\section{Case Study Area}

Quebec's Lower North Shore (LNS) is located on the northern edge of the Gulf of St. Lawrence (fig. 1). The region extends approximately $400 \mathrm{~km}$, from PointeNatashquan in the west $\left(50^{\circ} 05^{\prime} \mathrm{N}, 61^{\circ} 44^{\prime}\right.$ W) to its eastern limit at the Labrador border in Blanc-Sablon $\left(51^{\circ} 26^{\prime} \mathrm{N}, 57^{\circ} 08^{\prime} \mathrm{W}\right)$.
The climate is highly variable with continental and maritime air masses affecting the territory. The average temperature varies from $11^{\circ} \mathrm{C}$ in summer to $-11^{\circ} \mathrm{C}$ in winter. Summers are short and without frost and last only four months. There is a frequent presence of fog in summer. Annual precipitation totals 1,152 millimetres and the region receives an average of three metres of snow in winter. Sea ice often lasts until May, with icebergs frequenting the coast until mid-July (QLF, 2002).

The LNS is characterized as a drowned coastline with occasional promontories found near bays and rivers, and a string of

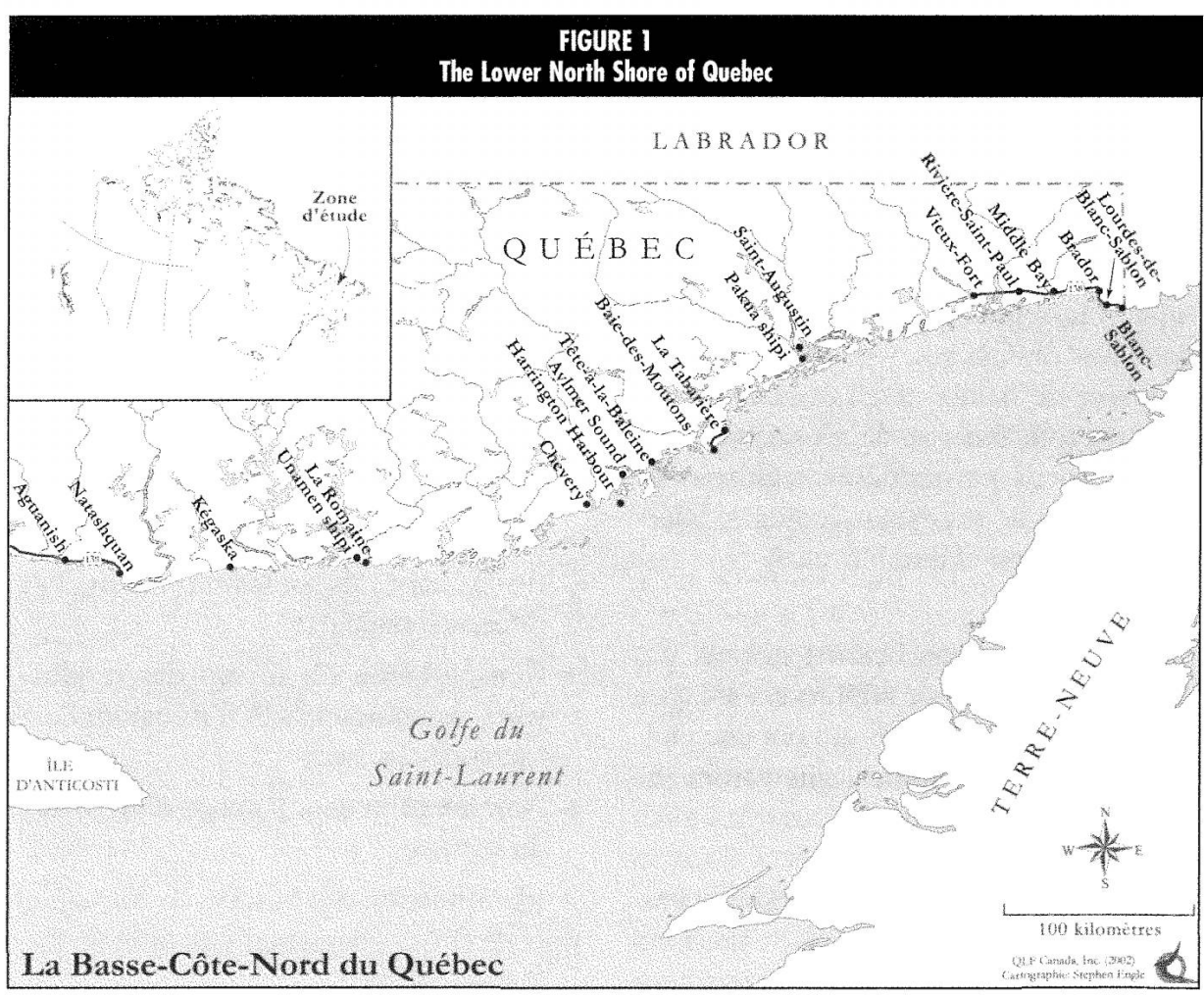


islands along the coast with ample evidence of glaciation. The region borders two great geological entities forming Eastern Canada: the Canadian Shield and the St. Lawrence Platform (Blanchard, 1984 : 117). The dominant hydrological feature of the region is the Gulf of St. Lawrence, which marks the southern limit of the LNS. Twenty-two salmon rivers of variable flow also drain the territory. Bédard (1969) identifies two predominant vegetation types along the coast-krummholz (shrubby thickets) and tundra. There are 38 species of land mammals and 25 species of fish have been classified, such as brook trout, northern pike, rainbow smelt, landlocked salmon, and Arctic char in some areas.

The region also has diverse marine fauna and flora. Marine birds total approximately 100,000 birds, with fifteen species as breeders nesting primarily in six migratory sanctuaries established in 1925 by the Canadian Wildlife Service. The largest breeding colony of Atlantic puffins in Quebec is located at the Bradore Bay Sanctuary in Lourdes-de-Blanc-Sablon, with a population of over 20,000 birds (Blanchard, 1994). Migrating shorebirds are also prevalent in the fall and spring, with 150 species of birds visiting the area annually (Nove, 1995). Today, the Gulf of St. Lawrence is a world-renowned site for observing marine mammals with one of the largest summer concentrations on the LNS between Old Fort and Blanc-Sablon (Fuchs and Sylvestre, 1995; Nove, 1995).

Culturally, the LNS has a rich and diverse ethnocultural heritage. Native prehistoric, Paleo-Eskimo, and Inuit archaeological sites up to 8,500 years old are found in the region (QLF 2002). The Montagnais stock who still inhabit the LNS exploit a wide range of plant and animal resources engaging in a subsistence lifestyle by fishing, hunting, and gathering (Blondin, 1984).

European archaeological sites from the $16^{\text {th }}$ to the $19^{\text {th }}$ centuries are also numerous due to an intensive exploitation of marine resources such as seal, salmon, cod, herring and whales. In the $16^{\text {th }}$ century, the LNS was settled each year by hundreds of fish- ermen at fishing posts scattered between Blanc-Sablon and Harrington Harbour including the Basques who hunted whales. In the $17^{\text {th }}$ century, the French settled more permanently on the LNS with New France claiming its rights and establishing the Commanderie du Labrador at Bradore Bay. The British Crown did likewise after the Conquest and, during the $19^{\text {th }}$ century, Jersey companies extended fishing activities in the region. Family-run enterprises formed the basis of the local economy. In the $21^{\text {st }}$ century, the cultural traditions are based on the presence of three cultures: the Montagnais, French, and English.

In 2002, the population of the LNS stands at approximately 5,780, spread across fifteen villages and two reserves (Institut de la statistique du Québec, 2002). The communities are divided into five political jurisdictions (fig. 2). Demographically, the region has a declining and ageing population with a high birth rate among native populations. English, French, and Montagnais are languages spoken in the region with $50 \%$ of the residents unilingual anglophones (Institut de la statistique du Québec, 1999). Formal education levels are low and employment is mainly seasonal.
Economically, the region is poorly diversified, affected by the decline in the fishery with annual unemployment rates of approximately $45.8 \%$ compared to $17 \%$ for the North Shore and $18.7 \%$ for GaspésieÎles-de-la-Madeleine (Institut de la statistique du Québec, 1999). Tourism is identified as a priority for development (QLF 2002).

Traditionally, tourism in the region has been largely controlled by outside tour operators. Since the early part of the $20^{\text {th }}$ century, with the arrival of the Clarke steamship lines in the Gulf of St. Lawrence, cruise ships have visited the region, transporting tourists from destinations such as Quebec City and Montreal. The early forms of tourist services in the region were outgrowths of industrial prospecting, such as forestry (Lundgren 1995). In 1919 as a result of steamship grants from the federal government, regular steamer services to Blanc-Sablon and other ports on the LNS commenced (Frenette et al., 1996).

From 1921 to 1969 , the Clarke Steamship Company was to dominate marine transportation in the Gulf of St. Lawrence, offering a fortnightly service during the

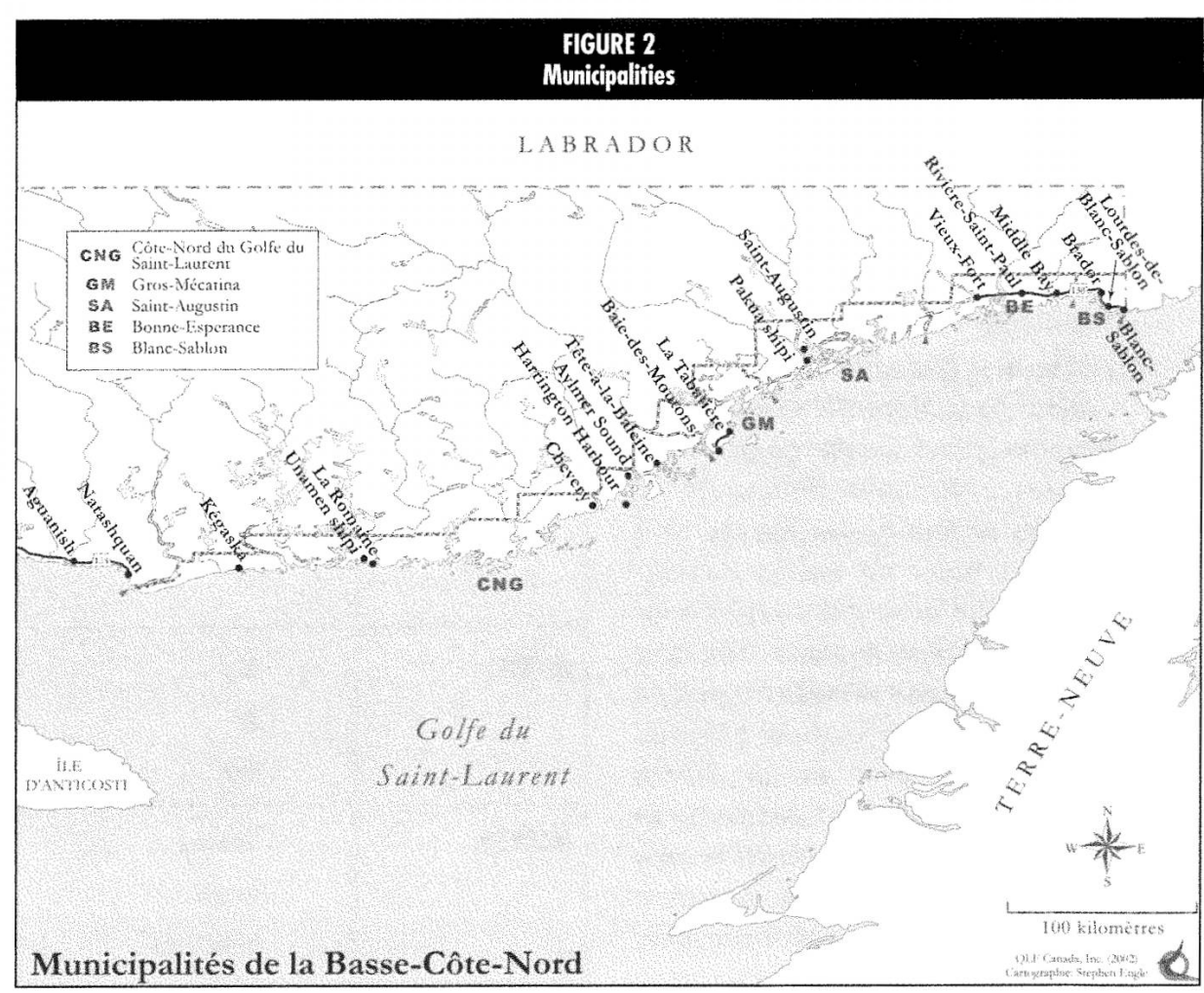


summer, transporting passengers, mail, and freight (Whiteley, 1975; Clarke Day Book, 1978). The first ships included the Labrador (1921-1930); the Gaspesia, later renamed the North Voyageur (1923-1950); and the North Shore (1921-33) (Franck, 1980). Those ships initially provided modest services, but also contributed to the expansion of trade to Newfoundland (Clarke Day Book, 1978). Even though the steamships were primarily designed to transport cargo, Louis Garnier, author of Dog Sled to Airplane: History of the Saint Lawrence North Shore, describes the time spent on the North Shore in a positive light: "One can never forget the fine spirit, friendly atmosphere, and good humour, which have been the hallmarks of our boats along the North Shore. All their passengers felt at home" (Garnier, 1949 : 172).

The scenery of the Gulf and the warm hospitality on the steamships led to the development of pleasure cruises in the region. From the 1920s until the outbreak of World War II, those pleasure cruises, departing every Monday in July and August from Montreal on a circuit of the Gulf of St. Lawrence, stopped on the LNS coast at Grenfell Medical Mission communities as well as the Hudson's Bay Company posts (Junek, 1937; Franck, 1980). In an entry from the Clarke Day Book (1978 : 54) it was reported:

The scenic splendours of the Gulf of St. Lawrence, which had first attracted the Clarke brothers, prompted the new line to develop pleasure cruises from Montreal to many picturesque ports in the Gulf. These cruises... brought thousands of tourists to this region for the first time. Labrador, the unknown country, became more than just a synonym for Polar Regions. The new cruises did much to make the people aware of the work of the Grenfell Medical Missions in the North Country and aided that enterprise in many ways, focusing attention on a region, which proved to be so rich in natural resources, which are now being developed.
After the war, the pleasure cruises were discontinued with Clarke Steamship lines offering cargo and passenger services (Franck, 1980).

In the last decade of the $20^{\text {th }}$ century, the number of visitors to the region on ferry and cruise ships increased by approximately 15\% (Transport Canada, 1988; Ministère des Transports du Québec, 1988; Jones, 1991) through marketing campaigns that offered an "ecotourism adventure to wild and barren landscapes where the visitor will be seduced by the warm hospitality offered by residents" (Tourism Quebec, 1995 : 35). The Relais Nordik and Écho des Mers, based at Rimouski, Quebec, and the Apollo based at St. Barbe, Newfoundland, are the major means of transport for visitors to the region in the summer months. Limited road access and the high cost of air travel continue to

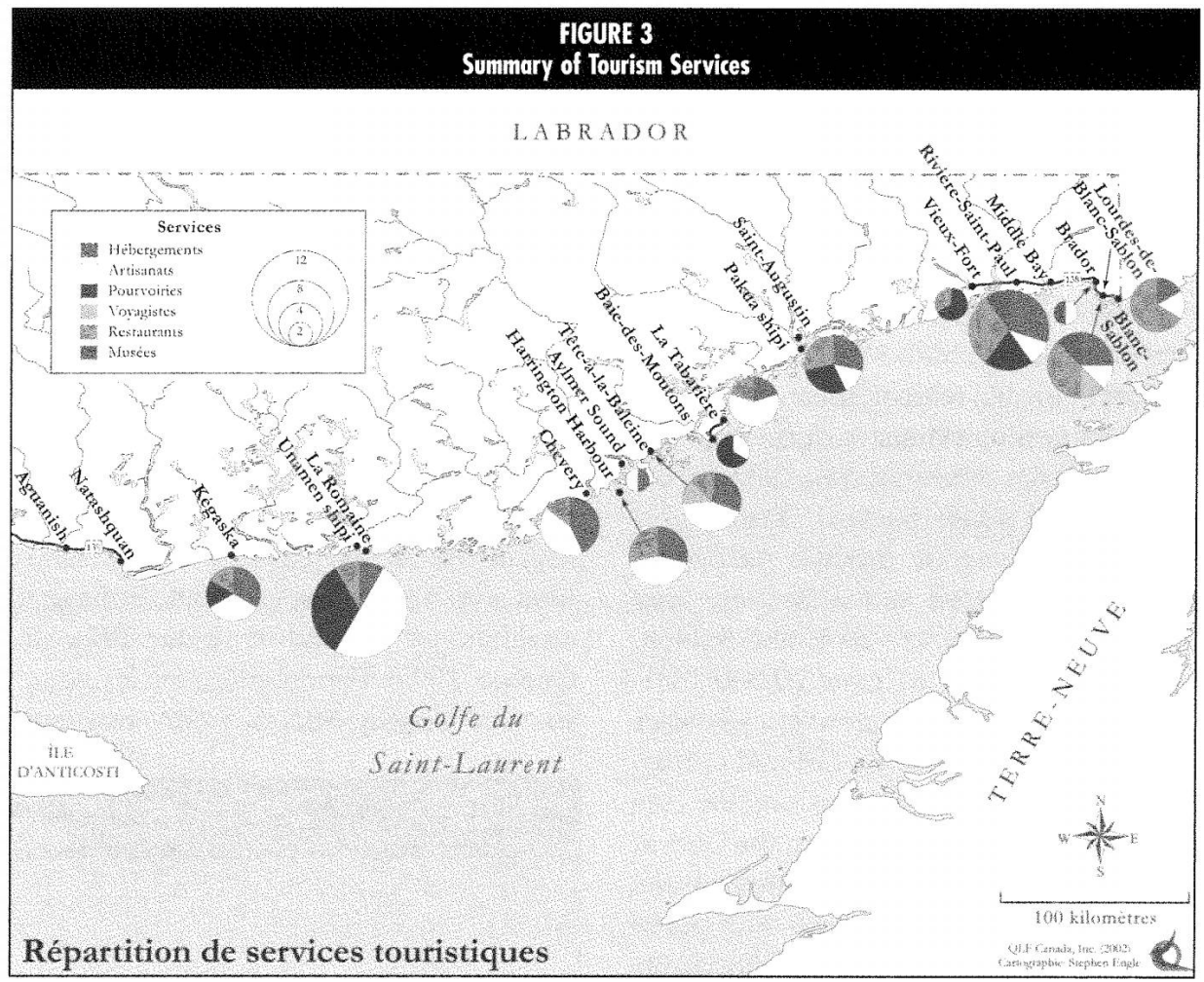

\begin{tabular}{|c|c|c|c|}
\hline \multicolumn{4}{|c|}{$\begin{array}{l}\text { TABIE } 1 \\
\text { Sub-Regional Evaluation of Tourism Product, Access and Markets }\end{array}$} \\
\hline & Easiern Region & Central Region & Western Region \\
\hline \multirow[t]{4}{*}{ PRODUCTS } & Archaeology & Living history & Aboriginal \\
\hline & Heritage & Birding & Outfitting \\
\hline & Wildlife viewing & Adventure & Crafts \\
\hline & & Cruising & \\
\hline \multirow[t]{3}{*}{ ACCESS } & Boat & Boat & Boat \\
\hline & Air & Air & Air \\
\hline & Road & Snowmobile & New road \\
\hline \multirow[t]{3}{*}{ MARKETS } & Maritimes & Quebec & Quebec \\
\hline & Ontario & Cruise ships & \\
\hline & United States & & \\
\hline
\end{tabular}


make maritime transport the most affordable means for visiting the region. Current levels of tourism activity are estimated at 10,000 visitors with the majority passing through the eastern sector on their way to Red Bay National Historic Site in Labrador (QLF, 2002; Parks Canada, 2001).

\section{The Lower North Shore Tourism Plan}

In 2001, the Comité ministériel permanent des affaires régionales et territoriales (COMART) to the Ministère des Régions du Québec announced a series of directives to respond to the LNS's lagging economy in a sustainable manner by preparing an action plan for economy recovery. The plan identified three priorities for development that include diversifying marine resources, developing a northern berry industry, and the development of ecotourism (Ministère des Finances et Ministère des Régions, 2001).

In 2001, the CLD hired the services of the Quebec-Labrador Foundation (QLF) and a team of consultants to develop a five-year tourism plan for the region. The consultant team was divided into seven groups-Environment, Culture, Economy, Access, Product, Market, and Education. The plan was prepared over a four-month period and divided into two major sections. Local residents participated in each group to assist in strategy development and data collection.

The first section of the plan, the inventory and analysis, provided a summary of the current state of affairs for tourism, an assessment of regional tourism conditions, and presented findings based on $110 \mathrm{com}$ bined interviews, surveys, and consultations with residents and industry professionals, plus extensive research by the planning team. Based on the findings, information on available tourism services was organized into a map inventory to assist the CLD and local residents in understanding the distribution of services in the region (fig. 3). The inventory also assisted the planning team in organizing the LNS into three sub-regional divisions for development. The three sub-regions were chosen as a result of differences in existing/potential products and services, access, and markets (Table 1). Based on the findings, a strategy was drafted for development that integrated the needs of the three sub-regions.

In Section two, the planning team proposed a gradual plan for ecotourism development

that involves a clear vision as well as a carefully managed, co-ordinated program for product development, marketing, education and training, and improved access to the region. Foremost in the vision is a commitment to sustainable practices, so as to protect the heritage and way of life and to ensure that tourism is complementary with other economic activities in the region ( $Q L F$ 2002).

\section{Nature-Based}

Blamey (2001) argues that in order for ecotourism to be sustainable it must be naturebased, environmentally and culturally educative, and sustainably managed. Nature-based tourism is primarily con- cerned with "direct enjoyment of some relatively undisturbed phenomenon of nature" (Valentine, 1992 : 108). The International Ecotourism Society (TIES) (1991) adds that, in a context of ecotourism, it must be travel to natural areas that is responsible and conserves the environment.

The LNS tourism plan identifies the creation of new destination trips, which are based on the strengths of the region's natural and cultural assets that will support ecotourism development. Sea kayaking, birding, archaeology and history, and ecoadventure are identified as a number of new target markets. The thousands of small islands and bays along the coast provide well-protected and accessible waters for kayakers. The six federally protected seabird sanctuaries, established in 1925 by the Canadian Wildlife Service, support thousands of seabirds. A visitor's code of conduct limits visitation to small groups at certain times of the year. Boardwalks and signage at St. Marys Islands and Bradore Bay sanctuaries are aimed at minimizing physical impacts, educating visitors about the diversity of marine birdlife, and offering wildlife view-

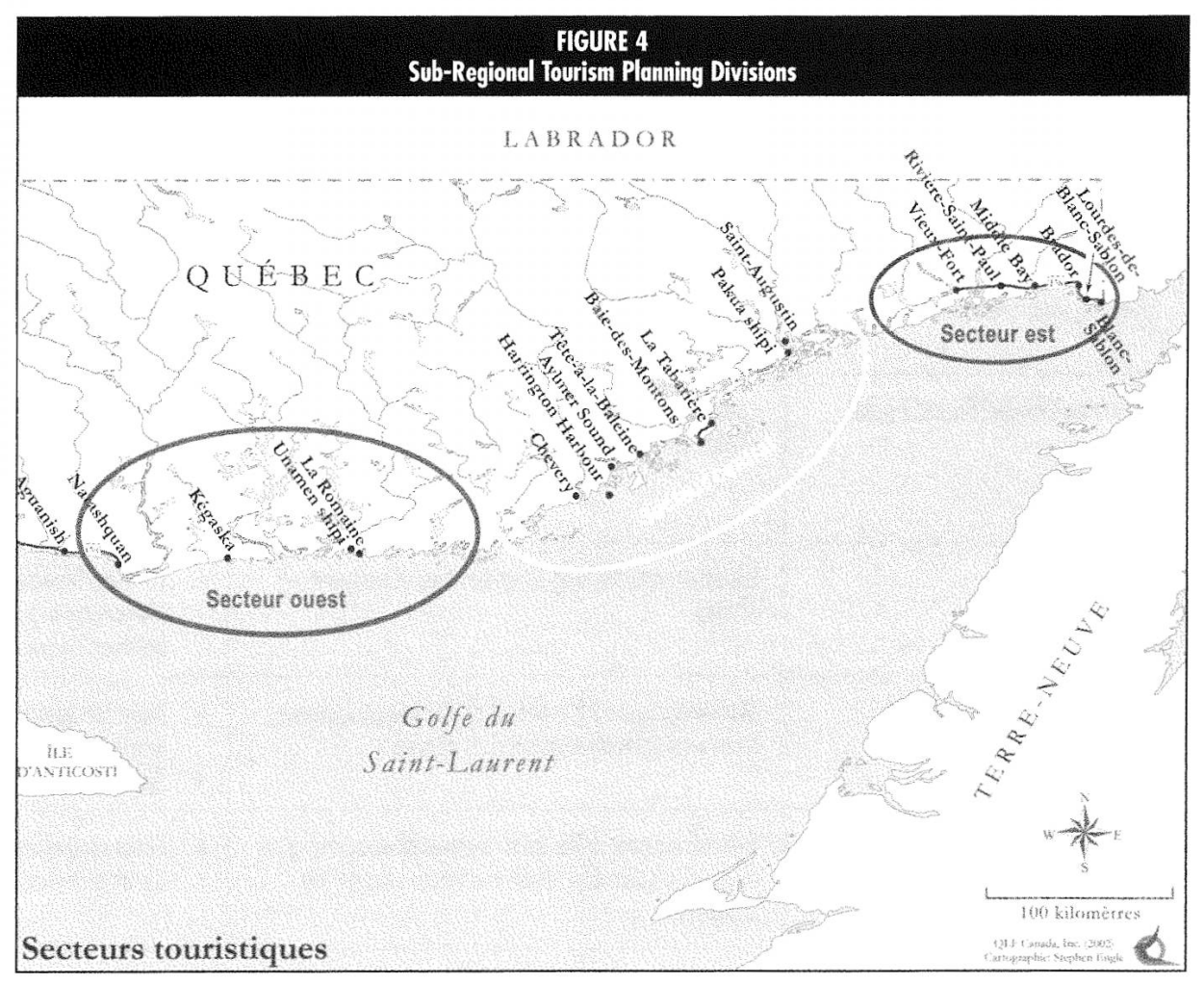


ing opportunities (Hull, 1998). The rich archaeological heritage, representing 9,000 years of human presence in the region, also provides a unique opportunity to understand the five cultures that have inhabited the region. Finally, the announcement in July 2002 by the Quebec Government, designating four new territorial reserves on the LNS, has increased the area under the IUCN's protected area classification system (IUCN, 1994) in the region from $2 \%$ to $78 \%$ (MEF, 2002). The establishment of the reserves will help protect the biodiversity of the region and will at the same time provide attractions for tourists.
Protected areas have been identified by policymakers as playing a key role in rural development strategies in remote areas such as the LNS (Brandon, 1996).

The development of those new destination trips will be attractive to the ecotourism market that is increasingly interested in adventuresome and personalized experiences in remote locales (Wight, 1996).

\section{Environmentally and Culturally Educative}

Blamey (2001 : 9) argues that, in implementing ecotourism strategies, there is the need to provide educational and interpretive programs about the natural environment and any associated "cultural manifestations" through activities that promote the use of original objects, first-hand experiences, and illustrative media.

As part of the LNS plan, the main focus of product development is to enhance a few significant existing attractions and package tours and then cluster additional activities and attractions that have the most potential around them. That strategy is aimed at providing the greatest economic impact for local development (QLF, 2002).

\begin{tabular}{|c|c|c|}
\hline \multicolumn{3}{|c|}{$\begin{array}{l}\text { TABLE } 2 \text { } \\
\text { Evaluation of Sustainable Tourism Principles in the Context of the Lower North Shore Plan }\end{array}$} \\
\hline $\begin{array}{l}\text { Sustainable Tourism Principles } \\
\text { (Tourism Concern, 1991) }\end{array}$ & Lower North Shore Tourism Plan & Main Challenges \\
\hline Using resources sustainably & Mentioned as key component of vision statement & - Putting theory into practice \\
\hline Reducing over consumption/waste & $\begin{array}{l}\text { Water, waste, energy addressed and evaluated } \\
\text { as part of plan }\end{array}$ & $\begin{array}{l}\text { - Region has limitations } \\
\text { - Water conservation measures needed } \\
\text { - Solid waste management programs in place in selected communities only } \\
\text { - Inadequate sewage disposal to handle large numbers of visitors } \\
\text { - Ample energy supply for industry }\end{array}$ \\
\hline Maintaining biodiversity & $\begin{array}{l}\text { Protected areas newly established in region by } \\
\text { Provincial Government Codes of Conduct developed } \\
\text { for marine sanctuaries }\end{array}$ & $\begin{array}{l}\text { - Negotiations between Provincial Government and local residents about access } \\
\text { and management issues for new reserves } \\
\text { - Many residents utilize resources (forestry, fishing, hunting) } \\
\text { - Fragile sub-arctic environment is subject to negative physical impact with } \\
\text { development of tourism }\end{array}$ \\
\hline Integrating tourism into planning & $\begin{array}{l}\text { Part of overall development strategy for region } \\
\text { proposed by Minister of Regions }\end{array}$ & $\begin{array}{l}\text { - Securing adequate support and funding to implement plan from tourism leaders } \\
\text { and government agencies will be critical in measuring success }\end{array}$ \\
\hline Supporting local economies & Funding available for tourism entrepreneurs & $\begin{array}{l}\text { - Strategic selection of businesses to receive funding will be important to provide } \\
\text { diversified strategy for development in region }\end{array}$ \\
\hline Involving local communities & $\begin{array}{l}\text { Clusters of activities in communities proposed } \\
\text { as part of plan }\end{array}$ & $\begin{array}{l}\text { - Local community associations and residents will need to be involved to } \\
\text { implement product development plan and to help coordinate initiatives }\end{array}$ \\
\hline Consulting stakeholders and public & $\begin{array}{l}\text { Communities and reserves consulted as part } \\
\text { of plan as well as outside operators and key actors }\end{array}$ & $\begin{array}{l}\text { Keeping stakeholders informed and involved in implementation phase will be } \\
\text { important as plan proceeds } \\
\text { - Traditional and new communication channels will need to be used-radio, } \\
\text { newspapers, general information meetings and Internet }\end{array}$ \\
\hline Training staff & $\begin{array}{l}\text { Education and training programs key component } \\
\text { of plan }\end{array}$ & $\begin{array}{l}\text { - Offering flexible programs in region that utilize innovative, hands-on methods } \\
\text { of learning in proximity to where participants live, due to large distances } \\
\text { between communities }\end{array}$ \\
\hline Marketing tourism responsibly & $\begin{array}{l}\text { Marketing approach is aimed at obtaining assistance } \\
\text { from outside marketing services agency }\end{array}$ & $\begin{array}{l}\text { - Need for outside marketing agency to work closely with CLD, in developing } \\
\text { marketing partnerships with operators } \\
\text { - Need to convey sustainable principles as part of marketing strategy }\end{array}$ \\
\hline Undertaking research & $\begin{array}{l}\text { Extensive research has been completed as part of plan } \\
\text { to provide necessary baseline data for monitoring } \\
\text { progress }\end{array}$ & $\begin{array}{l}\text { - Continuing efforts will be needed by CLD to evaluate and monitor progress of } \\
\text { development as plan is implemented }\end{array}$ \\
\hline
\end{tabular}


The Blanc-Sablon visitor's centre and interpretation circuit is one project identified as a proposed anchor attraction for the LNS. The centre will have a dual purpose as a gateway orientation centre by offering visitors available information on tourism products and services of the region. The centre will include exhibitions of artefacts and architectural elements prepared by the Ministère de la Culture et des Communications and will include interactive media, videos, and a website that interprets the landscape, the rich cultural heritage, and the diversity of archaeological sites.

In addition, the centre will offer opportunities to participate in interpretive tours of the LNS to discover the natural and cultural heritage of the region. Those tours will lead visitors "back" in time and will be organized as thematic discovery tours, with a local guide or self-guided leaflets, and will offer travel options by foot, car, bus, or boat (QLF, 2002). A local teacher at the school in Blanc-Sablon is interested in offering certified guide training courses for local students so that they can participate in the programming offered at the centre.

The tours offered by car and bus will be integrated into the Jacques-Cartier Trail, an interpretive driving tour of the region that features fifteen natural and cultural heritage sites along Route 138 in the eastern subsector of the LNS. The Trail was established in the 1990s and includes an orientation map, interpretive signage at pull-offs, and living history demonstrations by local residents at key sites along the route (Hull, 2001). In the summer of 2002 a local resident demonstrated the craft of boat building at the Bradore Bay Fishing Interpretation Centre, one of the stops on the trail.

The proposed Blanc-Sablon Interpretation Centre illustrates the small scale and personalized interpretive programming that is being developed to highlight the natural and cultural heritage of the region. Those educational characteristics are important considerations in the development of ecotourism at a destination (Blamey, 2001).

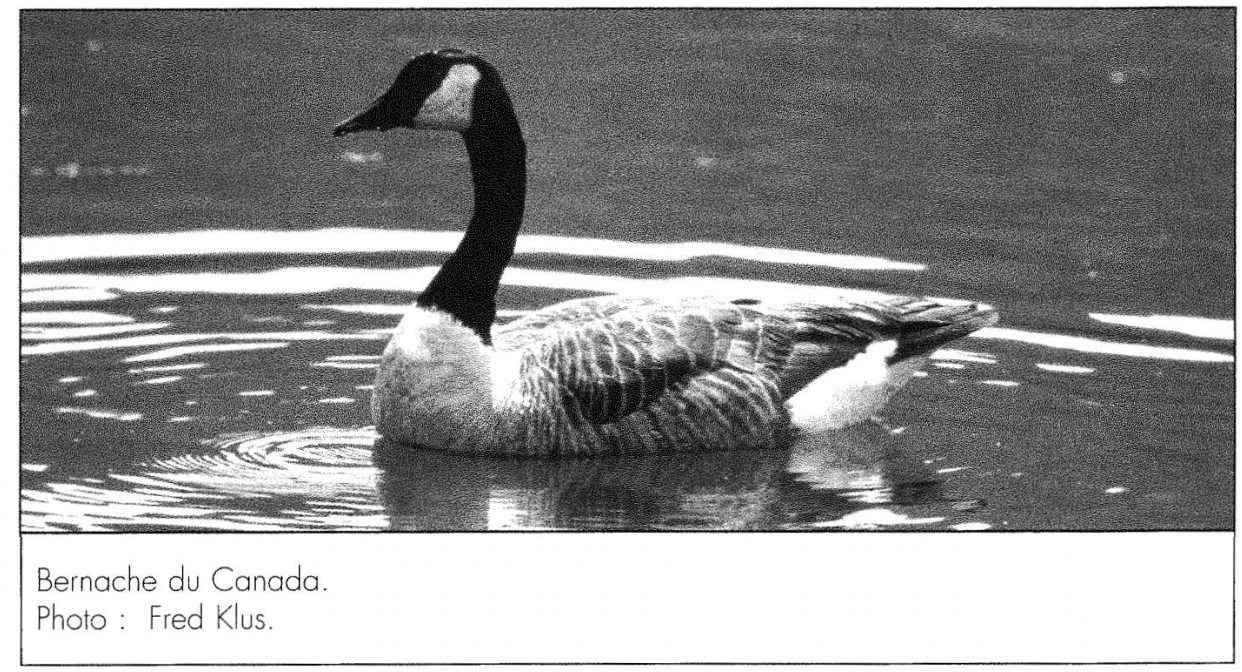

\section{Sustainably managed}

Many policymakers argue that ecotourism must be sustainably managed through the implementation of development strategies that balance tourism supply and demand and integrate principles of sustainable tourism (Inskeep, 1991; Wheeler, 1995; Blamey, 2001). The challenge for ecotourism planners is that there are significant gaps between policy endorsement and implementation (Berry and Ladkin, 1997; Garrod and Fyall, 1998). Table 2 provides an evaluation of the LNS tourism plan based on the principles for sustainable tourism outlined by Tourism Concern in 1991. The chart evaluates the degree to which those principles are addressed in the LNS plan and identifies challenges that the CLD will need to address as the plan is implemented in the region.

In reviewing the principles of sustainable tourism, the main challenge identified by the CLD and the provincial government at the initial stage of implementing the ecotourism plan, is to secure adequate support and funding from tourism leaders and government agencies to match available funding sources. A two-day workshop is planned by the CLD for the fall of 2002 to begin negotiations with key funding agencies.

\section{Conclusions}

The LNS is a vast wilderness region, with spectacular coastal scenery, abundant marine life, and a rich historic and ethno- graphic heritage (QLF, 2002). Due to the closure of the cod fishery in the region in the decade of the 1990s, unemployment levels remain high and the region's population base continues to decline. In 2001, the Provincial Government, working with the CLD, issued three directives for sustainable development that include diversifying marine resources, developing a northern berry industry, and the development of ecotourism.

The ecotourism plan completed in July 2002 by the QLF planning team provides an inventory and analysis of the LNS as well as a strategy for development that is nature-based, environmentally and culturally educative, and sustainably managed. The initial success of the plan will depend upon the degree of technical and financial support from public and private agencies to implement the strategy as well as the leadership of the CLD in fostering the longterm vision for sustainable tourism in the region.

John S. Hull is the Executive Director of the Viking Trail Tourism Association in Newfoundland and Labrador and was the project manager for the Lower North Shore Tourism Plan. He completed his Ph.D. at McGill University in 1998 addressing sustainable tourism development on the Lower North Shore of Quebec. He is also a research fellow for the New Zealand Tourism Research Institute (NZTRI) in Auckland, New Zealand. 


\section{Bibliography}

Bédard, J. (1969), Histoire naturelle du Gode Alca torda dans le Golfe St-Laurent, province de Québec, Canada, $\mathrm{n}^{\mathrm{0}}$ 7, Étude du Service canadien de la faune, Ottawa.

Berry, S., et A. Ladkin (1997), « Sustainable Tourism: A Regional Perspective », Tourism Management, vol. 18, p. 433-440.

Blamey, R.K. (2001), «Principles of ecotourism», dans David B. Weaver (ed.), Encyclopedia of Ecotourism. New York, CABI Publishing, p. 5-22.

Blanchard, K. (1984), Seabird Harvest and the Importance of Education in Seabird Management on the North Shore of the Gulf of St. Lawrence, Ph.D. Thesis, Ithaca, New York, Cornell University.

Blanchard, K. (1994), « Culture and Seabird Conservation: the North Shore of the Gulf of St. Lawrence, Canada », dans D. Nettleship, J. Burger and M. Gochfeld (eds.), Seabirds on Islands: Threats, Case Studies and Action Plans, Cambridge, England, Birdlife International, p. 294-310

Blondin, D. (1984), « People of the Land and People of the Sea », dans The Lower North Shore, Quebec City, Quebec, Minister of Cultural Affairs, p. 25-48.

Boyd, S. (2000), « Tourism, National Parks and Sustainability », dans R.W. Butler and S.W. Boyd (eds.), Tourism and National Parks: Issues and Implications, Toronto, John Wiley and Sons, p. 161-86.

Bramwell, B., et B. Lane. (1993), « Sustainable Tourism: An Evolving Global Approach », Journal of Sustainable Tourism, vol. 1, p. 1-5.

Brandon, K. (1996), Ecotourism and Conservation, Washington, D.C., World Bank.

Buckley, R. (1994), « A framework for Ecotourism », Annals of Tourism Research, vol. 21, p. 661-669.

Clarke Day Book (1978), Montreal, Quebec, Clarke Steamship Company.

Franck, A. (1980), Le Saint Laurent 1900-60, L'Islet-sur-Mer, Québec, Musée maritime du Québec.

Frenette, P., D. Chevrier, J.M. Dubois, P. Dufour, J.-C. Fortin, A. Lepage, J. Mailhot, F. Niellon, et N. Perron (eds) (1996), Histoire de la Côte-Nord, Ste-Foy, Québec, Institut québecois de recherche sur la culture.

Fuchs, A., et J.-P. Sylvestre (1995), « Québec: Le golfe du Saint-Laurent joue la carte du tourisme marin ", Mer et océan, vol. 5, octobre, p. 48-72.

Garnier, L. (1949), Dog Sled to Airplane: A History of the St. Lawrence North Shore, Quebec City, Quebec, n.p.

Garrod, B., and A. Fyall (1998), « Beyond the Rhetoric of Sustainable Tourism? », Tourism Management, vol. 19, p. 199-212.

Hull, J. (1998), Analysing the Potential for Tourism to Promote Sustainable Economic Development on the Lower North Shore of Quebec, Ph.D. Thesis, Montreal, Quebec, Geography Department, McGill University.

Hull, John S. (2001), « The Role of Heritage Corridor Development in Canada's Sub-Arctic: Promoting Identity, Networks and Innovation on the Lower North Shore of Quebec », in Jorgen Ole Baerenholdt and Nils Aaarsaether (eds.), Transforming the Local: Coping Strategies and Regional Policies, Copenhagen, Denmark, Nordic Council of Ministers.

Inskeep, E. (1991), Tourism Planning: An Integrated and Sustainable Approach, New York, Van Nostrand Reinholdt.

Institut de la statistique du Québec (1999), Direction des normes et de l'information, Québec, Québec.

Institut de la statistique du Québec (2002), Direction des statistiques socio-démographiques, janvier 29, 2002, Québec, Québec.

International Ecotourism Society (1991), The Ecotourism Society Newsletter, No. 1, Spring, North Bennington, Vermont.

IUCN - International Union of the Conservation of Nature (1994), Guidelines for Protected Area Management Categories, Gland, Switzerland, IUCN.

Jones, G. (1991), Le développement touristique de la zone Vieux-Fort/Blanc-Sablon en Basse-Côte-Nord du Golfe St-Laurent, Mémoire de maîtrise, Université du Québec à Rimouski, Rimouski, Québec.

Junek, O.W. (1937), Isolated Communities: A Study of a Labrador Fishing Village, New York, American Book Company.

Lundgren, J. (1995), « The Tourism Space Penetration Processes in Northern Canada and Scandanavia: A comparison », dans C.M. Hall and S. Staple (eds.), Polar Tourism: Tourism in the Arctic and Antarctic Regions, Toronto, John Wiley and Sons, p. 43-61.

MEF - Ministère de l'Environnement et de la Faune (2002), http://www.mef.gouv.qc.ca.
Ministère des Finances et Ministère des Régions (2001), La Basse-Côte-Nord: La stratégie et les moyens. 16 novembre 2000. Version finale, Québec, Gouvernement du Québec.

Ministère des Transports du Québec (1988), Statistiques de transports maritimes. Québec, Gouvernement du Québec.

Nove, J. (1995), Quebec Lower North Shore Visitor's Guide, Ipswich, Massachusetts, QLF/Atlantic Center for the Environment.

Parks Canada (2001), Visitation Statistics: Western Region of Newfoundland and Labrador. Rocky Harbour, Newfoundland, Regional Administration Office.

QLF - Quebec-Labrador Foundation (2002), Strategic Tourism Development Plan for the Quebec Lower North Shore, Montreal, Quebec, QLF Canada, Inc.

Ross, S., et G. Wall (1999), « Ecotourism: Towards Congruence Between Theory and Practice », Tourism Management, vol. 20, p. 123-132.

Tourism Concern (1991), Beyond the Green Horizon, Tourism Concern and WWF, London, Roehampton Institute.

Tourism Quebec/ATRD (1995), Côte-Nord: Manicouagan-Duplessis Tourist Guide Official Edition, 1995-7, Quebec, Tourism Quebec/ATRD.

Transport Canada (1988), Air and Maritime Transportation Statistics, Ottawa, Ontario, Transport Canada.

Valentine, P.S. (1992), « Review. Nature-Based Tourism », dans B. Weiler and C.M. Hall (eds.), Special Interest Tourism, London, Belhaven Press, p. 105-128.

Wheeler, B. (1995), « Ecotourism, Sustainable Tourism and the Environment - A Symbiotic, Symbolic or Shambolic Relationship? », dans A.V. Seaton (ed.), Tourism: The State of the Art, Brisbane, John Wiley and Sons, p. 647-654.

Whiteley, A. S. (1975), A Century on Bonne Espérance: The Saga of the Whiteley Family, Ottawa, n.p.

Wight, P. (1996), « North American Ecotourism Markets: Market Profile and Trip Characteristics », Journal of Travel Research, Spring, p. 2-10. 